\title{
Study on Art Talents Training Mode in Comprehensive University
}

\section{Liu Yi}

\section{Chongqing University of Education, CHONGQING,400067}

\begin{abstract}
Arteducation is animportant partofChinesehighereducationsystem, playing the role in fostering elegant aesthetic taste, motivating creative thinking and creating sound personality of students in colleges and universities. However, due to lack of managerial experience, faculty strength and other reasons, there are some problems in art education of comprehensive universities in our country. Therefore, in order to get out of this predicament, here we propose optimization strategies of art talents training mode in comprehensive universities.
\end{abstract}

KEYWORDS:Comprehensive University; Art Education; Training Mode

\section{Introduction}

Comprehensive university refers to the university with a full range of disciplines, including social sciences, natural science, business, law, medicine and other disciplines. Since the twentieth century, humans have entered the information age, when the information comes to explosive growth and disciplines become more and more refined. Development and differentiation of the discipline itself reflects the new achievements in the field of human activity and expansion of scientific research, thus forming a very significant feature of comprehensive universitymultidisciplinary. Multidisciplinary indicates that there should be multiple disciplines or colleges in a comprehensive university, and there should be some connection between these disciplines. Meanwhile, another significant characteristic of comprehensive university is its foundation. Disciplines in comprehensive university are mainly applied to the base, and the teaching content also focuses on basic science education.

Before 1988, popularization of arts education in China is relatively slow. Later in April, the State Education Commission formulated and issued"Advice to Popularize Art Education in Colleges and Universities", which marks the beginning of the popularity of art education in our country.

Art education is an important part of the comprehensive quality education, playing a positive role in promoting students' humanism and ideological quality. Currently, the vast majority of domestic comprehensive universities have opened art disciplines. The number of undergraduate arts student in some comprehensive universitieshas grown to overthat in art schools. If you count the students of vocational art school as well, the society has been a great deal of artistic talent.

\section{The Role of Art Education in Comprehensive Universities}

\section{A. Foster Elegant Aesthetic Taste}

The purpose of arts education is to foster the aesthetic taste of students, and then improve the harmonious development of students, which is 
also the direction of arts education. The essential attribute of art education is aesthetic education, and the first task is to cultivate students with aesthetic ability, to help the students to establish the aesthetic relation between art and reality, forming correct aesthetic standards.

Since art itself relies on auditory and visual to exist. With the help of melody, rhythm, color and other means, and associated with human body, mind and emotions, art brings a unique experience. This gives the most profound emotional experience, thus forming the infection in thought, so human will obtain aesthetic pleasure in emotional experience. In the implementation process of Arts Education, teachers can not only conduct rational inspirationthrough the expression of art emotion, making beauty more harmonious unity, but also organicallypermeate the elegant Aesthetic Taste into the class, with the help of lyrics, singing and pictures.

\section{B. Motivate the Creative Thinking}

The cultivation of creativity is an important goal of art education. Art education plays an important role in cultivating people's imagination capability and creative spirit. In a subtle way of infection, art education would produce a profound and far-reaching influence on people's spiritual world. Art education focuses on training of creative thinking, and should encourage students to innovate, so the student personality could get to play.

The research results of modern physiologyshow that, the human brain is divided into left part and right part: the left part has logic functions of calculation, comment and language; while the right part has functions of emotion, balance, image recognition, image thinking. Only when the both parts of the brain coordinate smoothly can human achieve a high intelligence. Music enjoy, singing and playing is an effective means to stimulate the emotions and develop image thinking, and is also a coordinated and harmonious movement, so it can promote the development of the right brain, and develop both the creative thinking and logical thinking. Especially ancient and modern boutique music appreciation and performance can inspire the emotions and feelings corresponding with musical movement form, subliming into rational thinking, and then produce practice full of passion. Such rational knowledge is beyond the phonetic symbol hierarchy, with a deep understanding of value, and is helpful for students understand, grasp and innovatively apply professional knowledge of nature, humanities disciplines, so that improving the learning effect and quality of students.

\section{Create a Sound Personality}

Art education as an important content of aesthetic educationlightens the previous functionalism values of knowledge education, skill education. Art education should pay more attention to students' capabilities of self-reflection, self-design and self-selection, playing an important role in shaping students' sound noble personality in higher education stage. Some art activities require all the members to coordinate, and form psychological sense of identity and cohesion. Any participation in art activities generally calls for strong self-discipline capability. For college students, they putting energy into the arts, proves that they put their feelings, that is, emotional expression and control, so it will make students beautify their words and deeds throughout the art activities. 


\section{Problems of Arts Disciplines in Comprehensive Universities}

\section{A. Training Objective Is Unclear}

For the existing higher arts education modes in our country, arts disciplines in artcolleges, teachers colleges and art research institutes all have clear positioning. Artcolleges mainly foster the skilled practice talents, who will be mainly engaged in creative or performance jobs; arts disciplines in teachers colleges mainly focus on cultivation of art educators; while the art research institutes aims to cultivate the art theorists. However, for comprehensive universities, there is still no clear directionabout what type of artistic talent to cultivate.

From the perspective of employment, if art disciplines construction strategy of comprehensive universities imitates any of the above modes, it will undoubtedly bring more pressure into the employment market that is already saturated, increasing the risk of structural unemployment of graduates. Therefore, the primary task of arts disciplines construction in a comprehensive university is clear positioning of training objectives. But the status quo is, most of the comprehensive universities still lose condition in art disciplines construction, and the graduates cannot be compared with the art college in the professional skills. These factors have restricted the benign development of art education in comprehensive university.

\section{B. Managerial Experience Is Inadequate}

If regarding the establishment ofArt Institute of Xiamen University in 1983 as the symbol, art disciplines construction in comprehensive universityhas justgone through 29 years. Most of comprehensive universities successively established their art colleges in the late 1990s. The time profiles to create art school of some key comprehensive university are shown in Table 1:

Table 1. Time Profiles To Create Art School Of Some Key Comprehensive University

\begin{tabular}{|c|c|c|c|c|c|}
\hline Year & University & Year & University & Year & University \\
\hline 1983 & XMU & 1994 & SEU, SCU, SDU & 2002 & TJU, DLUT \\
\hline 1984 & DHU & 1997 & PKU & 2003 & WHU, RUC, FZU \\
\hline 1985 & BNU, NWU & 1998 & THU, ZJU, NJU & 2004 & SCUT \\
\hline 1988 & NKU & 2000 & HIT, XJTU & 2005 & FDU, SWU \\
\hline 1993 & CSU, YSU & 2001 & $\begin{array}{c}\text { JLU, LZU, ZZU, NEU, } \\
\text { YZU }\end{array}$ & 2007 & CQU \\
\hline
\end{tabular}

As can be seen from the above data, there is still short time since comprehensive universities built arts disciplines in our country, without little referential and effective success experience. Higher art education at the university of the western counties is almost one hundred years earlier than us, and has formed a relatively mature and stable arts education system. We can learn from their experience, but it must be combined with china's national conditions, rather than a simple copy.

\section{Faculty Strength Is Weak}

Only with strong faculty strength can a university cultivate first-class talents. Since the art disciplines of comprehensive universities have been founded for a short time, people remain skeptical attitude towards its prospects. So the teacher strength of arts major cannot be compared with that of other majors in comprehensive universities, no matter in terms of quantity or quality. 
Statistical results oftotal number of full-time are shown in Table 2: art teacher in some comprehensive universities

Table 2. Total Number Of Full-Time Art Teacher In Some Universities

\begin{tabular}{|c|c|c|c|}
\hline University & $\begin{array}{c}\text { Number of full-time arts } \\
\text { teachers }\end{array}$ & $\begin{array}{c}\text { Number of arts } \\
\text { professors }\end{array}$ & $\begin{array}{c}\text { Number of arts associate } \\
\text { professors }\end{array}$ \\
\hline THU & 195 & 54 & 84 \\
\hline XMU & 103 & 16 & 27 \\
\hline TJU & 59 & 8 & 6 \\
\hline WHU & 35 & 6 & 12 \\
\hline SEU & 41 & 10 & 5 \\
\hline JLU & 65 & 14 & 7 \\
\hline LZU & 41 & 3 & 16 \\
\hline XJTU & 20 & 3 & 33 \\
\hline DLUT & 80 & 14 & 14 \\
\hline SUDA & 94 & 21 & 18 \\
\hline JSU & 91 & 6 & 15 \\
\hline FZU & 106 & 13 & compreh \\
\hline
\end{tabular}

As can be seen from the data above, in addition to a small number of universities, there is imbalance of the full-time arts teachers of most comprehensive between quantity and quality.

\section{Optimization of Art Talents Training Mode in Comprehensive Universities}

\section{A. Teaching Objectives Optimization}

It still has certain disparity between art education objective and the demand of the society. To change the current situation, comprehensive universities may base on their advantages of multidisciplinary, and should be oriented to the needs of the industry. According to industry needs changes, constantly adjust the training objectives, lesson plans, and curriculum system. Aiming to foster the overall quality of students and interdisciplinary knowledge structure, focus on operating practical ability cultivation and closely integrate theory and practice.

\section{B. Education Content Optimization}

Optimization of education content lies in curriculum system optimization. To optimize arts curriculum system of comprehensive universities, firstly it needs to combine with subject characteristics of comprehensive universities, especially cross disciplinary advantages. The curriculum system should not only embody the art professional training objectives, but also integrate arts professional features and integrated university school characteristics. In addition, according to the latest trends and scientific research of art disciplines, adjust the curriculum system, and adopt some new, informative and practical courses. Finally, educational administrators have to coordinate the relationship between public courses and elective courses, theory courses and practical courses, to achieve the optimal combination of teaching resources.

\section{Faculty Strength Optimization}

Faculty strengthdirectly determines the level and quality of teaching. Comprehensive universities could learn from professional art colleges, to employ a large number of practical talents to make up the short board. Encourage the arts teachers to go out for practice, and organize them to declare all kinds of subjects, to 
promote the combination of theoretical knowledge and practical application

\section{Teaching Methods Optimization}

Choosing a suitable teaching method can help to achieve teaching objectives. However, in current arts majors of comprehensive universities, the teaching methods are still simple and inefficient, lagging behind the social development. In terms of teaching methods, comprehensive should change the cramming teaching method, and adopt interactive teaching methods instead. Through the case study and discussion, it would arouse students' interest in learning, to enhance the students' abilities to analyze, discuss and solve the problems.

\section{Conclusion}

Art disciplines are developed rapidly in comprehensive universities, and in 2011, arts has officially become the thirteenth categories of science. However, the current position of arts disciplines and professions is still very awkward, and there are some obvious problems in art talents training process.

\section{REFERENCE:}

[1] Greer W D. Discipline-based art education: Approaching art as a subject of study[J]. Studies in art education, 1984: 212-218.

[2] Gardner H. Art education and human development[M]. Getty Publications, 1990.

[3] MA Y, XIAO Y. Curriculum and Talent Training of the Speciality MICE in China [J]. Tourism Science, 2005, 1: 012.

[4] Shu-ping H E. Innovation and Reconstruction of Creative Talent Training System in Higher Education [J]. Journal of Zhengzhou Institute of Aeronautical Industry Management, 2011, 6: 026.

[5] Guang-xue C. Exploration on Establishing the Talent Training System of Printing Major Adapted to Digitalizalion Reform [J]. China Printing and Packaging Study, 2012, 4: 003. 